\title{
INTERLOCKING CORPORATE DIRECTORATES AND THE GLOBAL CITY HIERARCHY
}

\author{
Jeffrey Kentor \\ Department of Sociology \\ University of Utah \\ kentor@soc.utah.edu
}

\author{
Adam Sobek \\ Department of Geography \\ University of Utah \\ info@geoinnovative.com
}

\author{
Michael Timberlake \\ Department of Sociology \\ University of Utah \\ timber@soc.utah.edu
}

\begin{abstract}
This paper examines the direct and indirect economic linkages of the most prominent cities in the world, those commonly referred to as "global cities", in terms of the direct and indirect linkages of the boards of directors of Fortune Global 500 firms headquartered in a given city with boards of directors of other firms. Specifically, we identify the interlocks of corporate boards located within these major cities with other Fortune 500 boards of directors by degrees of separation, and present a new ranking for selected global cities based upon these direct and indirect ties. We find that New York clearly dominates these economic linkages, followed by London and Paris. This is most pronounced for financial companies. Contrary to other global city rankings, we locate Tokyo below Frankfurt and Chicago on this dimension. We argue that these multiple levels of indirect relationships reflect a significant, and until now unexplored, dimension of what it means to be a "global" city.
\end{abstract}

\section{INTRODUCTION}

At least since Roderick McKenzie's classic essay theorizing about international influence of great cities (1927), many who have studied comparative urbanization, have concerned themselves with the relative influence of cities world wide. Sporadically until the 1980s, scholars in sociology, geography and urban planning have theorized about and recorded the mechanisms that give rise to a city's influence over social and geographic space. They have also worked at measuring the relative dominance of cities over immediate hinterlands, throughout broad geographic regions and across the globe (e.g., Hall, 1966). However, beginning in the last couple of decades of the twentieth century, there was an explosion of research on cities and globalization, much of it 
concerned with the relative influence of cities in the "new," globalized world economic order (e.g., Friedmann, 1986; Meyer, 1986; Sassen, 1991; Timberlake, 1985; Taylor, 1995). In recent years interest has hardly subsided, with research on the changing global influence of specific cities such as New York, London, and Tokyo (Sassen, 2002), New York, Chicago, and Los Angeles (Abu-Lughod, 1999), Shanghai (Cai and Sit, 2003; Wei and Leung, 2008), Hong Kong (Meyer 2000), Seoul (Shin and Timberlake 2006), Tokyo (Saito and Thornly, 2003), Johanesburg and Cape Town (Pirie, 2010), on urban-led growth regions (e.g., Chen 2001), on measuring the relative dominance of from three hundred (Taylor 2004) to more than three thousand cities in the world (e.g., Alderson and Beckfield 2002), and studies of changes over time in the relative important of cities relative to the world system of cities (Derudder et al., 2010) ${ }^{1}$.

This body of research rests on several observations and assumptions. First, global exchanges of information, commodities, and people (e.g., through migration) are increasingly rapid and globally ubiquitous. Second, therefore, a single world economy is increasingly displacing the relevance of national economies, if not of nations themselves. Third, the world economy is undeniably capitalist, and the important decisions behind many of the processes inherent in this world economy are made by individuals and groups who control the most important firms in the world economy. Fourth, there is a geography of global control that arises from the fact that these firms are place-based, with headquarters and branch offices located in specific cities around the world. Fifth, various incentives for geographic proximity exist that result in some cities becoming more import locations of decision making than other cities. In the language of McKenzie and the early urban ecologists, some cities are more dominant within systems of cities than other cities. Because the relevant scope of city systems is now global, there exists one world system of cities, unified by global flows of information, capital, and people among them. Moreover, this system is hierarchical with a few cities at the apex of dominance, and an increasing number of cities exerting less dominance (and evincing more subordination). ${ }^{2}$ Thus the research on world cities/global cities to date centers on cities' relative dominance in the global system of cities and cities' relative position as important sites of corporate control. The current effort extends world city research in another direction by operationalizing a new and different sociological inter-city relationship-one based on social ties across specific, key organizations-to establish the relative degree to which particular cities are embedded in the social wiring that links firms in a spatialized global corporate network.

\section{CONCEPTUAL AND OPERATIONAL DEVELOPMENT OF WORLD CITY ANALYSIS}

Though Geddes and Hall seem to have first used the term, "world city," it is Friedmann's and Sassen's conceptualizations that undergird most of the recent work on global urban hierarchy. Each regards global economic relations as primary in shaping this hierarchy, and each sees cities as nodes within regional and overarching world-wide urban networks. Friedmann (1986) identified thirty world cities on the basis of seven criteria of world "cityness" including the extent

\footnotetext{
${ }^{1}$ Taylor, et al. (2011) have produced a book that surveys some of the methods of world city analysis as well as descriptions of how many specific cities are situated in it.

${ }^{2}$ It is important to note that these theorists do not consider the city to be the operant actor. Rather, they conceptualize cities as sites of human activity and the built environment which facilitates these activities.
} 


\section{INTERLOCKING CORPORATE DIRECTORATES AND GLOBAL CITIES 500}

to which a city is home to major financial institutions, headquarters for TNCs; headquarters to international institutions; the rapidity with which the business service sector has grown; its importance as a manufacturing center; the extent to which it serves as a major transportation node; and its population size. He finds "a distinctively linear character of the world city system which connects, along East-West axis, three distinct sub-systems" (1986:72), including an Asian sub-system, a North American sub-system, and a West European sub-system, and he offers of a typology of world cities based on their scope of dominance, with "global articulates" used to refer to those atop the world system's city system. About a decade later, Friedmann expanded his list of world cities, and he acknowledged that the hierarchical ordering of world cities is contingent and subject to change over time due to the competitive and cyclical nature of capitalism (1995:25). At the top are New York, London, and Tokyo, which he classifies as "global financial articulations." Respectively, the other categories are "multinational articulations," "important national articulations," and "subnational/regional articulations." Friedmann also summarizes the state of knowledge at that time on world cities, arguing that we can identify five general areas of agreement. Global cities "...serve as the organizing nodes of the global economic system." Significant areas of the world are not articulated into the global capitalist system of accumulation and in these areas there are, essentially, "subsistence economies." World cities are big, populace, and characterized by frequent and dense social and economic interaction. Moreover, as we have seen, world cities are systematically and hierarchically arranged, and this arrangement, due to the competitive nature of global capitalism, is subject to rearrangement. Finally, the system that gives rise to this global hierarchy of world cities is one in which the interests of a particular social class are primarily represented. This is the "transnational capitalist class," whose very dominance, wealth, and power, represents social polarization which can be extreme within global cities (1995:26).

Sassen (e.g., 2000) offers us the related concept of "global cities" which correspond, roughly, to Friedmann's "global articulates" (see DeRudder 2006). These cities at the very top of the global urban hierarchy interest her because by focusing on them she solves a puzzle. Why, she asks, in an era in which people can communicate instantaneously, without the apparent "friction of space," do cities continue to be important, for example, as sites of the headquarters of the world's biggest corporations? Transnational corporations (TNCs) have dispersed many economic activities that had once been geographically concentrated; yet economic control continues to be concentrated spatially and organizationally. " ...it is precisely the combination of the global dispersal of economic activities and global integration - under conditions of continued concentration of economic ownership and control-that has contributed to a strategic role for certain major cities." Global cities are the global control centers of the world economy, sites of the marketplaces for the most important industries of the current world economy: finance and specialized services for firms. She identifies London, New York, and Tokyo as the three "global cities." Other cities are less influential than these three, with some sites for analogous control functions on a smaller scale. Like Friedmann, she sees a global network of cities that is hierarchical with respect to their scope of influence (e.g., dominance) (see Sassen 2002).

Unlike Friedman who "envisages global urbanization in terms of dominance and power" over (primarily economic) flows, she sees the basis for cities' degree of global dominance "in terms of the production of the inputs that constitute the capability for global control" (DeRudder, 2006).

Researchers have used a variety of measurement techniques in attempting to model urban hierarchies, including that of the global city network. There is a long tradition of modeling 
national city systems based on the distribution of the population sizes of cities, though population size was often recognized as the best available proxy for other potential (but unavailable) measures of "dominance" (cf. Berry and Kasarda 1977; Chase-Dunn 1985) . Friedmann's hierarchical classification $(1985,1995)$ of some thirty world cities into hierarchical was based on a number of characteristics of cities in addition to population size.

Christopher Ross (1996), an urban ecologist, studied the structure of city-systems within the United States. He argued that cities were essentially containers of organizations, and citysystems are, therefore, reflections of organizational networks, primarily corporate. The hierarchy of these city systems was determined by the relative power of the corporations residing within these cities in terms of their control over the economic activity in other cities. Ross operationalized these power relationships in terms of corporate headquarter and subsidiary locations. To the extent that a corporation headquartered in New York, for example, has a subsidiary in Pittsburgh, some amount of control or power is acquired by actors located in New York over Pittsburgh. The New York based corporation has an impact on employment and capital activities in Pittsburgh, which reduces the control that Pittsburgh policy makers and capitalists have over the city's economic activity. This set of assumptions is rooted in the research and theory in urban sociology of the 1960s and 1970s on community power and absentee corporate ownership (e.g., Walton 1967).

Ross created an organizational matrix to describe the city-system hierarchy in the U.S., by identifying the locations of corporate headquarters and their subsidiaries in major metropolitan areas in 1950 and 1980. Ross referred to these headquarter-subsidiary networks as "control linkages". He selected only manufacturing corporations for this study, arguing that industrial activity has a greater impact on a city's overall economic activity than primary or tertiary activities. ${ }^{3}$ Ross concluded from these analyses that a) urban systems are pyramidal in nature, with a few dominant cities at the top (New York and Chicago) and an increasing number of cities at lower levels of the hierarchy and b) dominance, or power, decreases at lower levels of these networks.

Taking a similar tack have been Peter Taylor and his associates with the Globalization and World Cities (GaWC) Study Group and Network which Taylor founded. In contrast to Ross (and Alderson and Beckfield--see below), their approach to empirically specifying the world's city system is focused on the organizational geography of producer services firms rather than firms in general. This selection criterion is consistent with Sassen's argument that global control is centered in the top firms specializing in accountancy, advertising, banking/finance, insurance, law, management consultancy. They map the world's leading producer service firms, including headquarters and branch offices across more than three hundred of the world's largest cities. Thus, the GaWC group produces a firm by city matrix. In doing so, they distinguish between five potential levels of a firm's presence in each city (e.g., being home to a firm's headquarters gives a city five points whereas no presence in a city gives the firm a zero presence in a city). Taylor (2002b) refers to their approach as an "interlocking model" because it is based on the interlocks of key firms across the world's cities-firms' organizational geographies serve to interlock cities (e.g., intra-organizational flows of information, resources, and personnel tie the headquarters in New York to the branch office in Pittsburgh). They argue that by centering their analysis on

\footnotetext{
${ }^{3}$ Meyer $(1984,1986)$ conducts similar analyses of financial networks in the Southern U.S., and South America.
} 


\section{INTERLOCKING CORPORATE DIRECTORATES AND GLOBAL CITIES 502}

firms rather than other relational characteristics of cities (see below) that they have targeted the units that can more properly said to have agency, rather than the cities in which the firms are located, which, without reifying, cannot normally be said "to act" (see Taylor, 2006). Their analysis calculates the top ten cities to be London, New York, Hong Kong, Paris, Tokyo, Singapore, Chicago, Milan, Los Angeles, and Madrid using one measure of "connectivity." However, Milan and Madrid drop out of the top 10 and are replaced by Frankfurt and Amsterdam when a different connectivity measure is used.

Preceding and overlapping the work of Taylor and GaWC group is that of Smith and Timberlake (e.g., 1993) who argued that these attribute-based measures of cities' relative dominance within systems would best be replaced by measurements based on relational data, making use of formal network analytic procedures. Later (e.g., 1995, 2001, 2002), they estimated global city hierarchies for various years between 1977 and 1995 using data on the volume of airline passengers flying between pairs of about 100 of the world's most important cities. Recognizing that airline passenger travel is not the most theoretically significant indicator of cityto-city flows, they argued that nonetheless it is a good proxy for other, more fundamental relations among cities (2002: 121-122). These data allowed them to use formal network analysis, the assumptions of which require measures of the presence/absence or magnitude of each dyadic relationship in the network. Using this approach in 2002, they found the top twelve cities for 1997 to be (in descending order of dominance), London, Frankfurt, Tokyo, and New York, followed by Seoul, Los Angeles, Hong Kong, Singapore, San Francisco, Madrid, Milan, and Chicago. Using different network measures of connectivity yield somewhat different lists of cities, but the differences are mostly minor (e.g., Smith and Timberlake 2002). Using more complete and less problematic air passenger flow data source, DeRudder and Witlox (2005) describe in more detail (i.e., more cities are included) the global system of cities based on air passenger travel. The advantage of using air passenger flows to describe world city hierarchy is that it is one of the few types of truly relational data that have so far been marshaled for cities world wide. Thus the powerful tools of formal network analysis are available to describe in great detail the resulting global network of cities. The weakness of the data lies in the uncertainty of how closely the relative volume of air passenger traffic reflects theoretically fundamental processes of world city formation (e.g., the flow of capital, commodities, etc.). This weakness is answered in the data used by the GaWC group that maps organizational hierarchy across cities on the basis of the world's largest producer service firms. However, the resulting data set does not lend itself to formal network analysis because it does not result in mapping inter-city relations directly.

Alderson and Beckfield (2004, 2006, 2007) and Alderson et al. (2010) manage to combine some of the strengths of both network analysis and the geography of the largest firms. In terms of the breadth of their coverage, they produced the most ambitious and nuanced empirical assessment of the global city system. Applying Ross's (1994) methodology, they assembled data on the city locations of 446 of the Fortune 500 largest multinational enterprises (MNEs) across 3,692 cities, linking city-to-city on the basis of the sum of its headquartersubsidiary relationships. Unlike the GaWC data, this produced a city-by-city matrix (like the air passenger data) which they then analyzed according to conventional social network analysis protocols. Their findings included four measures of network centrality: indegree, closeness, betweenness, and outdegree centrality. Following conventional network theory (Wasserman and Faust, 1994), Alderson and Beckfield characterize the first three measures as indicators of 
"power", and the final measure as "prestige". According to Taylor (2006) outdegree centrality is closest to the GaWC measure, "dominant network connectivity" (and the closest measure they have of overall network centrality). Tokyo tops Alderson's and Beckfield's city ranking on this measure with nearly $40 \%$ more outdegrees than New York, the second city in this ranking. The next highest ranking cities by outdegree are Paris, London, Dusseldorf, Amsterdam, Zurich, Munich, Osaka, and San Francisco, respectively. Taylor (2006) has written about the differences between his GaWC data (and analysis) and that of Alderson and Beckfield, which relies on headquarter-subsidiary locations to create a city-to-city matrix rather than a city-firm matrix. In Alderson and Beckfield, in-degree centrality (or prestige), which indicates the extent to which cities are chosen as locations for the Fortune 500 branch offices are New York, London, Paris, Tokyo, Los Angeles, Chicago, Brussels, Amsterdam, Singapore, and Hong Kong. They conclude their study with a block modeling of cities according to these centrality measures that generates 34 blocks, the top seven of which they label "primary". These are cities relatively high on both outdegree and indegree centrality. At the top of this group is a block comprised of London, New York, Paris, and Tokyo, which accounts for 37 percent of all outdegrees and 14 percent of all indegrees. The next two blocks in this group, which contain 38 additional cities, accounts for approximately $46 \%$ of all outdegrees and 30 percent of all indegrees. The next 3 blocks in their model are referred to as "high status cliques", with relatively high ratios of indegrees to outdegrees. While their data coverage is more extensive than the GaWC results, the Alderson and Beckfield findings are arguably less nuanced than the former because the data are not centered on producer services and their spatial organization. This undoubtedly accounts for their different findings. Recently researchers have collected other sorts of inter-city ties, identifying still other global city networks. These include those based on linking the ways in which cities are linked through collaborations between and among geographically separated scientists (Mathiessen et al., 2010) and those based on linkages via the internet backbone (Vinciguerra et al. 2010).

\section{A NEW DIMENSION OF THE GLOBAL CITY HIERARCHY}

Alderson and Beckfield's global headquarter-subsidiary perspective defines a global city hierarchy in terms of direct power relationships among cities, similar to Ross's (1996) notion of control linkages, or what Kentor (2005) refers to as "conduits of power." Following Sassen, Peter Taylor and his group understand the global city hierarchy in terms of the number and type of producer services firms located in a given city. Smith and Timberlake examined the extent to which cities exchanged travelers, many of them presumably business travelers, in order to estimate a city's importance to the world economy. Carroll (2007) begins to blaze a new path to global urban hierarchy, one which we follow, although with important differences. He focuses on the way in which powerful individuals knit together globally important corporations through their membership on multiple boards of directors of major corporations. When key firms that are situated in different cities share one or more board members, this constitutes an inter-city linkage. Carroll's research extends this across 350 top corporations (manufacturing as well as producer services). Identifying those with transnational interlocking directorates produces a network of forty-eight cities, and, when he includes "local" (within-country) linkages, seventy cities comprise the global network of cities based on interlocking boards of these 350 corporations. 
We follow this focus on interlocking directorates as a theoretically compelling empirical device through which to broaden our understanding and interpretation of global cities and global city networks. Like Carroll, we examine cities' positions within the global city hierarchy in terms of the linkages of the boards of directors (BoDs) of the world's largest firms which are headquartered in a given city with BoDs of other large firms. In addition to studying the direct linkages between these corporate boards, unlike Carroll, we also examine the indirect ties, or degrees of separation, between them. This is a very different, inter-organizational conceptualization of the global city hierarchy than those based on either headquarters and branch offices (intra-organizational) or on business travelers (non-organizational). It is a reflection of integration or embeddedness of a given city in the global economy, rather than an indicator of dominance and/or control. Membership in the network provides access to various resources, which are not readily available to those outside this network. We argue that this corporate connectedness is one aspect of what it means to be a "global" city. In order to understand our argument, it will be helpful to explain the concepts of "interlocking corporate directorates" and "degrees of separation", upon which our research is based.

\section{INTERLOCKING CORPORATE DIRECTORATES}

Interlocking corporate directorates exist when one individual sits on multiple boards of directors; They have been the focus of numerous studies spanning many academic disciplines (Mizruchi 1996), and much of the recent impetus for examining these interlocking directorates arises from the realization that corporations--more specifically transnational corporation--are increasingly significant actors in the global economy (McMichael 1996; Sklair 1995; Kentor 2005). One statistic is sufficient to highlight their growing power: of the 100 largest economies in the world today, 51 are corporations and 49 are countries (Anderson and Cavanaugh 2000). While some scholars would argue that corporations have completely eroded the power of nation-states and now dictate the policies that govern international relations (McMichael 1996; Sklair 2001), others argue that nations continue to exert significant control over these policies. Stopford and Strange (1991), for example, suggest that policies emerge from a complex three-way interaction among nations, transnational corporations and nationally oriented corporations.

These inter-corporate linkages have been the focus of numerous studies, spanning various academic disciplines (Mizruchi 1982, 1996). Much of the empirical work to date has explored the impact of these linkages on organizational performance, including collusive activities, information exchange, profitability, and the reduction of uncertainty (Haunschild and Beckman 1998). ${ }^{4}$ Researchers have more recently examined interlocking directorates in terms of a global business community (Kentor and Jang 2004, Carroll and Fennema 2002) or the emergence of a global elite (Robinson 2003).

There is a growing body of research indicating that board interlocks do, in fact, have significant impacts on a variety of corporate outcomes. Schoorman, Bazerman, and Atkin (1981) find that board interlocking is a profit maximizing strategy that reduces environmental uncertainty by horizontal coordination with competitors, vertical coordination with suppliers,

\footnotetext{
${ }^{4}$ It is important to note that the study of these corporate linkages gives us insight into the structure of control of these firms rather than the ownership of these organizations.
} 
acquisition of expertise, and/or enhancement of reputation. Davis (1991) shows that interlocks facilitate a diffusion of certain corporate practices such as "poison pill" strategies for avoiding hostile takeovers. Haunschild (1993), and Haunschild and Beckman (1998) also find that these networks influence corporate acquisition strategies. Davis and Greve (1997) conclude that modifications of corporate governance practices are influenced by interlocking directorates. Battiston, Weisbuch, and Bonabeau (2003) find that interlocked boards tend to make the same decisions about general topics. Finally, Burris (2005) presents empirical support for his argument that political cohesion within the business community is facilitated by these networks.

\section{SIX DEGREES OF SEPARATION}

This term was popularized by Milgram and colleagues (Milgram 1967; Travers and Milgram 1969). Using field experiments to trace acquaintance chains, Milgram explored the notion of "six degrees of separation" - that any two individuals selected randomly from the population can be connected via a chain of six links. We extend this concept of "six degrees of separation" to add to our understanding of the global hierarchy of cities. The idea here is that these indirect linkages between the firms provide broader (though weaker) access to other companies than direct ties between BoDs. The question we asked is how closely linked are the world's 500 largest companies. How many steps does it take for a given G500 firm to reach any other G500 firm? Further, does this "reach" vary by city, industry, and/or location (domestic or international)? These are the questions to which we now turn.

\section{EMPIRICAL ANALYSES}

We are not attempting here to construct a comprehensive ranking of the world's major cities, such as that provided by Alderson and Beckfield. Rather, we are exploring a new dimension by which to understand a global urban hierarchy - the direct and indirect ties between boards of directors of large corporations located in a given city. Therefore, we limit our analyses to only six major cities; New York, London, Tokyo, Paris, Frankfurt, and Chicago. The first three of these were originally classified by Sassen (1991 edition of Sassen, 2002) as the preeminent "global cities". Paris also attains preeminent global status in more recent rankings of Alderson and Beckfield (2004), Beaverstock and Taylor (1999), and Smith and Timberlake (e.g., 2003). Frankfurt and Chicago are included as representatives of a second, regional, tier of major cities. For reasons of resource constraints, we include only the world's 500 largest companies in terms of revenues, identified as the Fortune Global 500 (FG500). The corporate interlock data are taken from Kentor and Jang (2004).

The initial step in the analyses was to identify those Fortune Global 500 (FG500) firms located in the six cities being evaluated, their type of industry, and the names of the directors of these corporations. Next, we charted the interlocks among these corporations, irrespective of industry. We then examined two industry groups, financial and manufacturing. Finally, we examine the indirect linkages among these global firms by degrees of separation. Unlike Milgram, we focus on the first three degrees of separation. This is where most of the variation across cities occurs and is likely to be the furthest distance at which meaningful influence occurs. 


\section{RESULTS}

\section{Geographic Distribution of Fortune Global 500 Firms}

Table 1 gives the geographic distribution of the FG500 firms by city and nation. The U.S. contains 186, or 37\%, of these companies, of which 24 are located in New York and 4 in Chicago. Japan is headquarters to 100 (20\%) of the FG500 firms, 74 of which are located in Tokyo. Germany is home for 42 FG500 companies, with 8 of these headquartered in Frankfurt. London contains 33 of the 40 FG500 firms located in the U.K., and Paris holds 35 of the 39 FG500 firms headquartered in France.

Table 1. Number of FG500 Firms Headquartered in Selected Cities and Countries, 1998.

\begin{tabular}{|c|c|c|c|c|}
\hline \multicolumn{2}{|c|}{ \# FG500 } & \multicolumn{3}{|c|}{ \# FG500 } \\
\hline City & Firms & Nation & Firms & City/Nation \\
\hline Chicago & 4 & US & 186 & .02 \\
\hline Frankfurt & 8 & Germany & 42 & .19 \\
\hline London & 33 & UK & 40 & .82 \\
\hline New York & 24 & US & 186 & .13 \\
\hline Paris & 35 & France & 39 & .90 \\
\hline Tokyo & $\underline{74}$ & Japan & 100 & .74 \\
\hline Total & 178 & $36 \%$ & 407 & $81 \%$ \\
\hline
\end{tabular}

\section{Total Linkages}

However, a predominance of FG500 firms in a given city does not necessarily reflect that city's "connectedness" or "embeddedness" in the global urban network. So the next step of our analysis is to examine the linkages between these corporations, in terms of interlocking boards of directors. These data are presented in Table 2. The 24 FG500 firms located in New York have 201 direct links with other FG500 companies by shared directors. These 201 FG500 companies, in turn, have 1212 links with other FG500 firms. In other words, the 24 NY firms have 1212 links 
to other FG500 firms by 2 degrees of separation. At three degrees of separation, these 24 companies have 2965 ties with other FG500 companies.

Table 2. Number of Corporate Board Interlocks of FG500 Firms in Selected Cities with Other FG500 Firms in 1998, By Industry.

\section{\# Total FG500 Firms in City \\ One Degree of Separation \\ \# of Total Interlocks \\ \# of Interlocks / Firm}

Two Degrees of Separation

$$
\text { \# of Total Interlocks }
$$

\# of Interlocks / Firm

Three Degrees of Separation

\# of Total Interlocks

\# of Interlocks / Firm

\# Financial FG500 Firms in City

One Degree of Separation

\# of Total Interlocks

\# of Interlocks / Firm

Two Degrees of Separation

\# of Total Interlocks

\# of Interlocks / Firm

Three Degrees of Separation

\# of Total Interlocks

\# of Interlocks / Firm

\# Manufacturing FG500 Firms in City

One Degree of Separation

\# of Total Interlocks

\# of Interlocks / Firm

Two Degrees of Separation

\# of Total Interlocks

\# of Interlocks / Firm

Three Degrees of Separation

\# of Total Interlocks

\# of Interlocks / Firm
34

34

100

100

\section{Chicag
4}

41

10

261

65

676

169

$\underline{1}$

5

5

132

132

\section{$\underline{1}$}

17

17

190

190
303

101
119

39.7

rankfurt
$\mathbf{8}$
49
6

217
27

423

1212

51
York
24

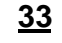

Paris

35

Tokyo

75

201

139

44

1

$\begin{array}{ccccc}529 & 1535 & 2968 & 1532 & 303 \\ 66 & 21 & 124 & 44 & 4 \\ \underline{4} & \underline{\mathbf{1 1}} & \underline{\mathbf{1 3}} & \underline{\mathbf{9}} & \underline{\mathbf{1 8}} \\ 25 & 27 & 113 & 43 & 16 \\ 6 & 3 & 9 & 5 & 1\end{array}$

98

81

618

148

44

25

7

48

16

2

226

273

1492

387

150

57

25

115

43

8

$\underline{3} \quad \underline{9}$

\section{$\underline{6}$}

9

$\underline{30}$

24

17

45

49

15

2

8

5

1

43

1.4

$\begin{array}{llll}142 & 329 & 223 & \\ 15.8 & 54.8 & 24.8 & 1.4\end{array}$

$\begin{array}{lccc}477 & 813 & 619 & 109\end{array}$




\section{INTERLOCKING CORPORATE DIRECTORATES AND GLOBAL CITIES 508}

Parisian FG500 firms are the next most connected of our six cities, though approximately half fewer than New York firms. These 35 Parisian companies have 139 linkages with other Boards of Directors at one degree of separation, 557 links at two degrees, and 1532 ties at three degrees of separation. Turning to the other cities in our analyses, we find that the number of interlocks for 33 London FG500 firms grow from 75, 423, to 1535 links at one through three degrees of separation. FG500 firms in Frankfurt and Chicago, our two "second tier" cities, have significantly fewer linkages than those of New York, Paris, or London. The 8 Frankfurt firms have 49, 217, and 529 linkages with other BoDs at one through three degrees of separation respectively, while the 4 Chicago FG500 firms have 41, 261, and 676 ties with other firms at one through three degrees of separation. Of the six cities under consideration, Tokyo is the most surprising. Although Tokyo contains by far the most FG500 firms (74), its firms have fewer interlocks than our "minor" cities of Frankfurt and Chicago, and are just a fraction of those exhibited by firms located in New York, Paris, or London. The 74 FG500 firms located in Tokyo interlock directly with only 44 other FG500 firms. This grows to 108 interlocks at two degrees and 303 linkages at three degrees of separation. In total, these four countries account for $81 \%$ (407) of the World's 500 largest corporations, with our six cities alone containing nearly $36 \%$ (178) of these.

\section{Linkages by Industries: Financial and Manufacturing}

We now turn to an examination of linkages between boards of directors for specific types of companies, beginning with financial firms. There is an established literature indicating that historically at least - financial firms were the most likely of all industry types to be interlocked with other BoDs (Mintz and Schwartz 1987), although recent research suggests that this may no longer be the case (Davis and Mizruchi 1999). Here we examine the direct and indirect linkages of FG500 financial firms in a given city with any other FG500 firm located elsewhere. Our findings are presented in Table 1. New York financial firms are dominant, both directly an indirectly. The 13 financial FG500 BoDs in New York have 113 links with other FG500 BoDs. Those 113 firms, in turn, have 618 ties to other FG500 BoDs. This grows to 1492 linkages at 3 degrees of separation. Paris and London present similar patterns. Paris contains 9 financial FG500 firms, which have 43 ties with other FG500 firms. This grows to 148 and 387 linkages at 2 and 3 degrees of separation. The 11 London financial FG500 firms have 27 direct interlocks with other FG500 firms, which grow to 81 and 273 linkages at 2 and 3 degrees of separation. Frankfort, with 4 FG500 financial firms, has 25 direct interlocks and 98 and 226 interlocks at 2 and 3 degrees of separation. The single Chicago FG500 financial company has 5 interlocks with other FG500 firms at one degree of separation, which expands to 34 and 132 ties at 2 and 3 degrees of separation. Tokyo is, once again, an anomaly. There are 18 financial FG500 firms headquartered in this city, the most of any city we examine. However, it has an interlock structure more similar to those of Frankfurt or Chicago than to the more "global" cities with which it is generally classified. These 18 financial firms have only 16 interlocks with other FG500 firms. These 16 firms, in turn, have 44 interlocks with other FG500 BoDs, growing to 150 links at 3 degrees of separation.

The interlock structure for manufacturing firms is perhaps the most surprising. Tokyo, with more of these FG500 firms (29) than our other five cities combined, has the fewest number of interlocks, with 15, 43, and 109 links, respectively. Paris contains 6 manufacturing firms, 
which have interlocks with 49, 223, and 619 other FG500 BoDs. The 6 manufacturing based firms in London interlock with fewer other FG500 companies; 17, 142, and 477 at 1 to 3 degrees of separation. New York firms are the most frequent interlockers, though not dramatically, with 45, 329, and 813 ties, respectively. Frankfurt firms connect with 24, 119, and 303 other BoDs at 3 degrees of separation. Finally, the sole Chicago manufacturing company links to 17, 100, and 109 other FG500 boards at the three degrees of separation.

\section{Tendency to Interlock}

Our six cities also vary by the tendency of their respective FG500 firms to interlock with other FG500 companies, and the tendency of those companies to connect with subsequent FG500 BoDs, as shown in Table 2. FG500 Firms in the two U.S. cities have the greatest tendency to interlock with other FG500 firms. The 4 Chicago firms average 10 interlocks per firm at one degree of separation. This grows to 65 interlocks/firm at two degrees of separation and 169 interlocks/firm at three degrees. The average interlocks per firm for New York companies ranges from 8 at one degree to 124 at three degrees. The 35 Parisian firms average between 4 and 44 interlocks at one to three degrees of separation, while the 8 Frankfurt FG500 companies interlock with an average of 6,27 , and 66 other BoDs over the three degrees of separation. London firms are less likely to interlock than the above cities, averaging only 2 to 21 interlocks per firm at one to three degrees of separation. Tokyo based companies, however, have by far the lowest averages, ranging from less than 1 interlock per firm at one degree of separation to an average of 4 interlocks per firm at three degrees.

An examination of the interlock tendency data by industry highlights New York financial firms' strength, vis-à-vis financial firms in other cities. The 13 financial firms in New York have 113 direct interlocks with other FG500 firms, or an average of 9 interlocks per firm. These 113 connections, in turn, generate 618 linkages, more than a five-fold growth and an average of 48 interlocks/firm. This grows to 1492 ties at three degrees of separation, nearly a $250 \%$ increase, with an average of 115 interlocks per firm. The 11 London FG500 financial companies exhibit a much lower interlock rate, expanding from 27 links at one degree of separation to 273 interlocks at three degrees of separations. These companies average 3 interlocks at one degree, which grows to 25 interlocks/firm at three degrees. Tokyo, with the largest concentration of FG500 financial firms, has the lowest connectivity. These companies average less than one direct interlock and 8 links at three degrees of separation.

New York manufacturing firms are also the most highly interlocked, although the differences with firms in other cities are not so striking. The six manufacturing companies headquartered in New York have 45 direct ties with other FG500 firms, which expands to 813 links at three degree. This results in an average of 8 interlocks per firm at one degree and 136 interlocks per firm at three degrees. This is approximately double the number of interlocks for the 9 Parisian manufacturing firms, which are the second most interlocked companies of those studied. What is most striking, however, is that the numeric dominance of the 30 Tokyo manufacturing firms generates the fewest interlocks of those cities studied, averaging less than one direct link per firm, and less than 4 interlocks/firm at three degrees. This is a dramatic contrast with the single manufacturing FG500 firm in Chicago, which has 17 direct interlocks and 190 interlocks at three degrees of separation. 


\section{DISCUSSION AND CONCLUSION}

Several findings stand out. First, our analyses of direct and indirect corporate interlock networks suggest that current measures of global city hierarchies may be missing an important aspect of what it means to be a "global" city. Using our uniquely social measure of corporate integration, New York firms are the most interlocked and Parisian firms are next, with roughly half the number of interlocks. London companies are third, Frankfurt fourth, and Chicago fifth. Tokyo companies, which are numerically dominant in all categories, are the least integrated with other FG500 firms. This hierarchy is very different from the previous measures discussed above, particularly regarding Tokyo. By concentrating on how common board members link the top corporations we are able to capture classic sociological dimensions of individual power, prestige, and privilege that render particular individuals as constitutive links in the social networks of economic globalization. When we trace the locations of the firms thus linked, we are able to map the embededness of the cities where these firms are located in the global corporate network. Cities are thus embedded not only by the number of key firms tied in them but also by the nature and number of social ties to other major firms.

Second, it is evident from our findings that a small group of cities, and their respective nations, dominate the transnational corporate world. The six cities examined here account for $36 \%$ of the Fortune Global 500 corporations and their countries are headquarters of over $80 \%$ of these mammoth firms.

Further, our research suggests that some scholars have exaggerated the extent to which it is reasonable to see a global system of cities as constituting a network that operates somehow independently of nations, states, and the interstate system (though see Alderson et al., 2010 and Mahutga et al., 2010, for more evidence to the contrary of this "deterritorialization" claim) . Firms are influenced and constrained by their respective nations, and these differences bear upon the extent and nature of how the cities in which these firms are sited are interlinked. New York and Chicago firms exhibit similar interlock tendencies, which differ from those of firms in European and Asian cities. While Japan is a dominant economic force in the global economy with $20 \%$ of world's largest companies, Tokyo firms are surprisingly absent from this "club", a consequence of national laws that prohibit this corporate integration. However other Asian cities, such as Seoul, are also excluded from this network. Cities appear to be constrained by the nations within which they are located, at least on this dimension of global integration. These findings question the notion put forth by many urban scholars who suggest that global cities are independent of their respective countries (Sassen 2002).

Third, it is worth noting that some of these cities seem to dominate the corporate landscape in their respective countries, as shown in Table 5. London, for example, contains $87 \%$ of all British FG500 firms. Similarly, 89\% of all French FG500 companies are located in Paris. Japanese firms are also highly concentrated in Tokyo, with $74 \%$ of all Japanese companies. Conversely, German and U.S. corporations are less concentrated. Only 20\% of all German firms are located in Frankfurt. And New York, which dominates the global city network by our measure, contains only $13 \%$ of all U.S. FG500 companies. This corporate concentration may 


\section{JOURNAL OF WORLD-SYSTEMS RESEARCH}

reflect a new aspect of what is referred to in the urbanization literature as "primate" cities (Smith 1985; London 1987; Walters 1985; Portes 2003). ${ }^{5}$

Finally, it is evident from these findings that the global economy remains the business of a small club, one which appears difficult to join. Tokyo's (and Japan's) inability to integrate with what is largely a North Atlantic network, despite its numeric dominance, raises many questions for further study, the most obvious of which is whether this lack of integration is one of the causes of Japan's prolonged recession.

One final question not addressed here concerns the causal relationships of these corporate interlocks. Or put another way, to what extent do these direct and indirect corporate networks make a city "global", or do global cities attract these highly networked firms? Most likely it is both, but to what extent and over what period are questions left to future research.

We hope that the research reported here will be seen as an important first step in persuading scholars of the global city hierarchy to consider another dimension of what it means to be a "global city." We suggest that the spatiality of inter-corporate integration in the global economy needs to be considered along with factors like the spatial distribution of intra-firm corporate headquarter-subsidiary networks operations (the GaWC research and Alderson and Beckfield) and centrality in transportation networks (Smith/Timberlake and Derudder/ Witlox), Ideally, a multi-dimensional measure of global cityness will be constructed that includes all of these measures.

\section{ACKNOWLEDGEMENTS}

This research was supported, in part, by the National Science Foundation, Award ID: 0350078. Please direct all correspondence to Jeffrey Kentor, Department of Sociology, University of Utah 84121 (kentor@soc.utah.edu).

\section{REFERENCES}

Abu-Lughod, Janet. 1999. New York, Los Angeles, and Chicago: America's World Cities. Minneapolis: University of Minnesota Press.

Alderson, Arthur S. and Jason Beckfield. 2004. "Power and Position in the World City System." American Journal of Sociology 109:811-851.

. 2006. "Globalization and the World City System: Preliminary Results from a Longitudinal Data Set " in Cities in Globalization: Practices, Policies, and Theories, edited by Peter Taylor, Ben Derudder, Pieter Saey, and Frank Witlox. London: Routledge.

. 2007. "Globalization and the World City System: Preliminary Results from a Longitudinal Data Set " Pp. 21-36 in Cities in Globalization: Practices, Policies, and Theories, edited by P. Taylor, B. Derudder, Pieter Saey, and F. Witlox. London: Routledge.

\footnotetext{
${ }^{5}$ Urban scholars have long considered Paris and, to a less extent, London to be "primate" on the traditional measures of this concept.
} 


\section{INTERLOCKING CORPORATE DIRECTORATES AND GLOBAL CITIES 512}

Alderson, Arthur, Jason Beckfield, Jessica Sprague-Jones .2010. "Inter-City Relations And Globalization: The Evolution Of The Global Urban Hierarchy, 1981-2007." Urban Studies August 47:1899-1933.

Anderson, Sarah and John Cavanaugh. 2000. Top 200: The Rise of Global Corporate Power. New York: Global Policy Forum.

Battiston, Stefano, Gerard Weisbuch and Eric Bonabeau. 2003. "Decision Spread in the Corporate Board Network." Advances in Complex Systems 6:4: 631-644.

Beaverstock, J.V., R. G. Smith, and P. J. Taylor. 1999. "A Roster of World Cities." Cities $16: 445-458$.

Beckman, Christine and Pamela Haunschild. 1998. "When Do Interlocks Matter? Alternate Sources of Information and Interlock Influence." Administrative Science Quarterly Vol 43:815-844.

Berry, Brian and John Kasarda. 1977. Contemporary Urban Ecology. New York. McMillan.

Burris, Val. 2005. "Interlocking Directorates and Political Cohesion among Corporate Elites." American Journal of Sociology 111: 249-283.

Cai, Jianming and Victor F.S. Sit. 2003. Measuring World City Formation-The Case of Shanghai. The Annals of Regional Science 37:435-446.

Carroll, William and Meindert Fennema. 2002. "Is There a Transnational Business Community?" International Sociology: 17:393-419.

Carroll, William. 2007. "Global cities in the Global Corporate Network." Environment and Planning A: 39:2297-2323.

Chase-Dunn, Christopher. 1985. "The System of World Cities, A.D. 800-1975,"in M. Timberlake, (ed.), Urbanization in the World-Economy. Orlando, FL: Academic Press.

Chen, Xiangming. 2005. As Borders Bend: Transnational Spaces on the Pacific Rim. Rowman \& Littlefield Publishers.

Davis, Gerald. 1991. Agents Without Principles? The Spread of the Poison Pill Through the Intercorporate Network. Administrative Science Quarterly 36:583-613.

Davis, Gerald and Henrich R. Greve. 1997. "Corporate Elite Networks and Governance Changes in the 1980s." American Journal of Sociology 103:1-37.

Davis, Gerald and Mark S. Mizruchi. 1999. "The Money Center Cannot Hold: Commercial Banks in the U.S. System of Corporate Governance." Administrative Science Quarterly 44:215239.

Davis, Gerald F., Mina Yoo, and Wayne E. Baker. 2003. "The Small World of the Corporate Elite, 1982-2001." Strategic Organization 1:301-326.

Derudder, Ben. 2006. "On Conceptual Confusion in Empirical Analyses of a Transnational Urban Network." Urban Studies 43:2027-2046.

Derudder, Ben and Witlox F. 2005. "An Appraisal of the Use of Airline Data in Assessing the World City Network: a Research Note on Data." Urban Studies 42:2371-2388.

Friedmann, John. 1986. "The World City Hypothesis." Development and Change 17:69-84. . 1995. "Where We Stand: A Decade of World City Research." in Paul. L. Knox and Peter J. Taylor (eds.), World Cities in a World-System. New York: Cambridge University Press.

Hall, Peter. 1966. The World Cities. New York: McGraw Hill.

Haunschild, Pamela. 1993. "The Impact of Interlocks on Corporate Acquisition Activity." Administrative Science Quarterly 38:564-592. 
Kentor, Jeffrey. 2004. "Quantifying Hegemony in the World-Economy", in Thomas Reifer (ed.), Globalization, Hegemony and Power. Paradigm Press.

. 2005. "The Growth of Transnational Corporate Networks 1962 - 1998." Journal of World Systems Research 11:263-286.

Kentor, Jeffrey and Yong Suk Jang. 2004. "Yes, There is a Transnational Business Community." International Sociology 19:355-368.

Mahutga, Matthew C., Xiulian Ma, David Smith, and Michael Timberlake. 2010. "Economic Globalization and the Structure of the World-City System: The Case of Airline Passenger Data" Urban Studies 9:1925-1947.

Matthiessen, Christian., Annette Winkel Schwarz, Soren Find. 2010. "World Cities of Scientific Knowledge: Systems, Networks and Potential Dynamics. An Analysis Based on Bibliometric Indicators", Urban Studies 47:1879-1897.

McKenzie, Roderick. 1927. "The Concept of Dominance and World-Organization." American Journal of Sociology 33:28-42.

McMichael, Philip. 1996. "Globalization: Myths and Realities." Rural Sociology 61:25-55.

Meyer, David. 1986. "The World System of Cities: Relations Between International Financial Metropolises and South American Cities." Social Forces 64:553-581.

. 1984. "System of Cities Dynamics in Newly Industrializing Nations." Studies in Comparative International Development 21:3-22. 2000. Hong Kong as a Global Metropolis. Cambridge: Cambridge University Press.

Milgram, Stanley. 1967. "The Small World Problem." Psychology Today 2:60-67.

Mintz, Beth and Michael Schwartz. 1987. The Power Structure of American Business. Chicago: University of Chicago Press.

Mizruchi, Mark S. 1982. The American Corporate Network: 1904-1974. Beverly Hills, CA: Sage Publications.

. "What Do Interlocks Do? An Analysis, Critique, and Assessment of Research on Interlocking Directorates." Annual Review of Sociology 22: 271-99.

Pirie, Gordon. 2010. "Trajectories of North-South City Inter-relations: Johannesburg and Cape Town, 1994-2007." Urban Studies 47:1985-2002.

Robinson, William. 2003. "The Debate on Globalization: The Transnational Capitalist Class and the Transnational State," in Wilma Dunaway (ed.), New Theoretical Directions for the $21^{\text {st }}$ Century World-System. Greenwood Press.

Ross, Christopher. 1994. The Urban system and networks of corporate control. Greenwich, CT: JAI Press.

Saito, A. and A. Thornhley. 2003. "Shifts in Tokyo's World City Status and the Urban Planning Response. Urban Studies 40:665-685.

Sassen, Saskia. 2002. Cities in a World Economy. 2nd Edition. Thousand Oaks, CA: Pine Forge/Sage.

. 2002, The Global City: New York, London, Tokyo. $2^{\text {nd }}$ edition. Princeton, NJ: Princeton University Press.

Schoorman, F. David., Max H. Bazerman and Robert S. Atkin. 1981. "A Strategy for Reducing Environmental Uncertainly." The Academy of Management Review 241-251.

Shin, Kyoung-Ho, and Michael Timberlake. 2000. "World Cities in Asia: Cliques, Centrality and Connectedness." Urban Studies 37:2257-2285. 


\section{INTERLOCKING CORPORATE DIRECTORATES AND GLOBAL CITIES 514}

Sklair, Leslie. 1995. Sociology of the Global System. $2^{\text {nd }}$ Edition. Baltimore: Johns Hopkins University Press. 2001. The Transnational Capitalist Class. Oxford: Blackwell Publishers.

Smith, David A., and Michael Timberlake. 1993. "World Cities: A Political Economy/Global Network Approach," in Ray Hutchinson (ed.)., Research in Urban Sociology, volume 3: Urban Sociology in Transition. JAI Press.

. 1995. "Conceptualizing and Mapping the Structure of World System's City System." Urban Studies 32:287-302.

. 2001. "World City Networks and Hierarchies, 1977-1997." American Behavioral Scientist, 44:1656-1678.

. 2002. "Hierarchies of Dominance Among World Cities: A Network Approach." In Saskia Sassen (ed.), Global Networks, Linked Cities. London: Routledge.

Stopford, John, and Susan Strange. 1991. Rival States, Rival Firms: Competition for World Market Shares. Cambridge: Cambridge University Press.

Taylor Peter J. 1995. "World Cities and Territorial States: The Rise and Fall of Their Mutuality" in Knox, Peter L. and Peter J. Taylor (eds.), World Cities in a World System. Cambridge: Cambridge University Press. . 2006. "Parallel Paths to Understanding Global Intercity Relations." American Journal of Sociology 112:881-94.

Taylor Peter J., Gordon Catalano, and David R. F. Walker. 2002a. "Exploratory Analysis of the World City Network." Urban Studies 39:2377-2394.

Taylor Peter J., David R.F. Walker, and JohnV. Beaverstock.. 2002b. "Firms and Their Global Service Networks," in S. Sassen (ed.), Global Networks, Linked Cities, edited by S. Sassen. New York: Routledge.

Taylor Peter J., Pengfai Ni, Ben Derudder, Michael Hoyler, Jin Huang, and Frank Witlox. 2011. Global Urban Analysis: A Survey of Cities in Globalization. London: Earthscan.

Timberlake, Michael, ed. 1985. Urbanization in the World Economy. Orlando: Academic Press.

Travers, Jeffrey and Stanley Milgram. 1969. "An Experimental Study of the Small World Problem." Sociometry 425-443.

Vinciguerra, Sandra, Koen Frenken, Marco Valente. 2010. "The Geography of Internet Infrastructure: An Evolutionary Simulation Approach Based on Preferential Attachment." Urban Studies 47:1969-1984.

Walton, John. 1967. "The Vertical Axis of Community Organization and the Structure of Power." Social Science Quarterly 48:353-368.

Wasserman, Stanley and Katherine Faust. 1994. Social Network Analysis: Method and Application. New York: Cambridge University Press.

Wei, Yehua H. D., and Chi Kin Leung. 2005. "Development Zones, Foreign Investment, and Global City Formation in Shanghai". Growth and Change 36:16-40.

Yusuf, Shahid and Weiping Wu, 2002, "Pathways to a World City: Shanghai Rising in an Era of Globalisation." Urban Studies 39:1213-1240. 